\title{
VIEWPOINTS
}

\section{Peace and Security: The Islamic Understanding}

\author{
Karim D. Crow*
}

Man lā yarḥam ${ }^{u}$ lā yurḥam.

(One who does not practise compassion/show loving-kindness

toward others is not shown compassion/loving-kindness [by God]).

Prophet Muhammad

It is frequently said that the religion of Islam was first presented and understood as a salvational doctrine of peace through outward submission and inner surrender. The most essential value at the heart of Islam may be characterised as 'security/peace' (see the qur'ānic terms silm and salm). Today this assertion is radically questioned by many non-Muslims, who emphasise the combative role of a militant faith intent on conquest and dominion - a medieval European perception now cultivated among intelligence and security establishments countering terrorism. But how should we properly understand the original context and meaning of peace in Islam? Inherent in its historical appearance was an integral connection of 'peace-making' with 'security'. This may help to grasp the intent and conception of an authentic Islamic understanding of peace. It also becomes relevant now to take into account the current appreciation of the role of religion in establishing and promoting 'human security'. We mean the concept of 'human security' in its dialogic relations linking the field of development and that of security and conflict studies, including peace and conflict-resolution studies.

\section{Human Security}

The term 'human security' appeared in mainstream development circles with the 1994 global Human Development Report ${ }^{1}$ and was the subject of a 2003 Global Commission co-chaired by Sadako Ogata and Nobel Laureate Amartya Sen. ${ }^{2}$ Yet it previously had its own proponents and critiques within security studies among

* Karim D. Crow is Principal Research Fellow at IAIS Malaysia. This contribution is the first of an ongoing series treating 'Islamic Peace' from historical, theoretical, and pragmatic perspectives with the intent of rejuvenating authentic Islamic teachings of peace-building. 
scholars who for decades argued the pros and cons of expanding the notion of 'security'. Some have argued that the concept of security should be broadened to include underdevelopment as a threat. Yet a realist school rejects the inclusion of social, human and economic threats in the same category as 'national security'. ${ }^{3}$ Traditionally security has been defined as a function of protection of the interests of the State. But many critics and human rights practitioners maintain this is a narrow, state-centric, and ultimately counter-productive usage of the term security. These critics perceive that it is the level of the individual and his or her innate rights that most needs protection from perceived threats. ${ }^{4}$ Such privileging of the individual might be extended further to embrace also the wellbeing of the collectivity or the community. As the need to find concerted, collective responses to new threats became increasingly clear, human security conceived in terms of the link between security and development became a topic of reform agendas during the 2004-05 period in the United Nations and in regional organisations such as the European Union and ASEAN.

\section{Security/Peace}

There exists an intimate connection between al-Isläm with 'peace-making' and 'peaceful security'. Linguistic and qur'ānic evidence confirm this connection. The concept of peace is primarily associated with Arabic verbal nouns derived from the root $S-L-M$ (salimalyaslamu). The main nouns from this base form are salämah, salm or silm, and salām. In Classical Arabic, the term salm, 'peace-making', denotes the opposite of harb, 'war'. Yet widespread contemporary Arabic usage of salām (lit. 'salutations conveying assurance of safety and peaceful'security') generally understands it to connote 'peace' - whether positive or negative peace. ${ }^{5}$ Verbal form IV aslama, 'to deliver up, surrender, resign oneself to', may also signify inqā $d a$, 'to follow/obey', 'yield', 'submit', and its verbal noun is isläm.

Linguistic sources emphasise that al-Isläm (as the name for the religious polity established by the Prophet Muhammad) is etymologically derived from al-salāmah 'safety/security from harm' or 'avoidance of defects/vices'. According to the early philologist al-Khalīl b. Aḥmad (d. c. 791), who authored the first etymologic dictionary in Arabic, "al-salām conveys the meaning of al-salāmah, so the saying by the people al-salāmu 'alaykum denotes 'salämah from God be upon you' [...]. Al-islām denotes al-istislām, 'seeking conformity' to God's command, which is submission to His obedience and acceptance of His bidding (al-inqiyād li-ța 'atihi wa 'l-qabül li-amrih)." In other words, al-isläm is conjoined and coincides with the idea of providing assurance of safety and security from harm conveyed by the term al-salām ('salutations of security/peace' guaranteeing peaceful intent and security). To enter into the religion of al-Isläm meant 'to enter into peace/security' (al-silm). 
The semantic scope of several verbal roots overlaps in meaning with salima, where salāmah or salām is taken as equivalent to amān/surety as well as șulh/ conciliation - while the root $S-L-M$ possesses undeniable primacy.

- S S-L-H: șulh and ișlāh, 'conciliation' and 'peace-making' - in resolving conflicts between individuals or groups to ensure the harmony of the wider community, central to the key qur'ānic teaching on ending conflict: așlith ${ }^{u}$ dhāt baynikum ${ }^{6}$ ("and do you rightly dispose-order the case that is between you and be of one accord in unison") - quite simply 'peace-making'. Muslims must be of one accord after divisions over spilt blood, disputed property or rivalries, and act reciprocally with justice and equity (al-muqsitūn).

- ' $-M-N$ : amn and amān, 'safety/security/assurance of peace'; and $\bar{\imath} m \bar{a} n$, 'faith/ secure belief (safeguarding from perdition)'. While the legal application of amān (public security) in the external political sphere is well-known, the extension of islām into the interior domain of $\bar{\imath} m \bar{a} n$ is a crucial pairing which is all too often overlooked.

- $S-B-R$ : sabr, 'long-suffering patience' and 'endurance of suffering for a higher cause'. This fundamental virtue has strong links with jihād 'total striving', which opens out to the pursuit of security.

These closely related concepts amplify the meanings of 'safety/security', 'faith/ salvation', flowing from submission islām. The total context requires one to align all such terms together for the full range of meaning to manifest. Isläm signifies the safety and security experienced in acts of mutual harmony and concord between humans arising out of the inner peace between individual creatures and the Creator. It is valid to state that the name al-Isläm points to the real purpose and source of true security, namely to draw close to the ultimate origin of Peace: God. A famous utterance of the Prophet confirms this most fundamental Islamic notion: "The muslim is one from whom the Muslims are securely-safe from (harmful effects of) his tongue and his hand / al-muslim man salima l-muslimūna min lisānihi wa yadih." "The core meaning 'safety from harm' and 'security from evil' is evident.

\section{Peace-Making}

The Qur'ān employs al-silm peace-reconciliation as an attribute of salvational-faith $\bar{i} m \bar{a} n$, and/or as synonymous with the religious polity of isläm established by God's Messenger. It was generally held that silm is equivalent to or closely parallels salm. The second chapter of the Qur'ān, al-Baqarah, states:

yā ayyuhā l-lladhīna āmanū adkhulū fí 'l-silmi kāffatan [...].

(O you who believe, enter ye into silm all together) (2:208) 
Commentators recognised the possibility of both readings in Qur'ān 2:208 either as silm (=al-islām) or as salm (=al-sulh). ${ }^{8}$ Yet in Qur'ān 8:61 the term salm 'peace-making' clearly signifies the antonym of 'war/bloodshed' and may be construed in the sense of al-șulh: ${ }^{9}$

[...] wa in janahū li 'l-salmi fa-'jnaḥ la-hā wa tawakkal 'alā Llāhi innah" huwa 'l-samī'u 'l- 'alìm

([...] Yet if they then incline toward peace, then do you likewise incline, and rely utterly on God [O Muhammad] for He is All-Hearing All-Knowing)

This directive for șulh is conditioned upon the best interests of the Muslims: that al-Islām be manifested over 'un-faith' (the Arab pagans). The unspoken directive implied at the beginning of this verse is explicitly supplied by the renowned exegete al-Tabarī (d. 923): "When you suspect deceit and duplicity, then deal with them in the same manner by announcing hostilities. [...] As for initiating the inviting of them to peaceful-reconciliation șulh, this is not found in the Qur'ān."10 In other words, the initiative for peace-making in the conflict with those of un-faith (the Arab idolaters) is entirely dependent upon their intentions and actions - a practical soberly cautious position. If the opposing party freely inclines to peaceful-reconciliation (negotiating a treaty), or accepts to render jizyah and be subjugated, then al-salm, 'peace-making' (= al-sulh) is divinely bidden. There must always be a peaceful response in response to a peace-making initiative offered by the opposing party.

Al-Ṭabarī also reviewed the dissension between leading authorities among the Successors over whether Qur'ān 8:61 bidding șulh had been abrogated by one or another of the so-called 'fighting' verses bidding Muslims to combat pagan idolaters unequivocally without respite (e.g., Qur'ān 9:5, 29, and 36). Many asserted that the earlier divine bidding to respond peacefully to peace-making initiatives was now abrogated, and God's bidding henceforth enjoined unmitigated fighting against them until they made resignation and proclaimed "There is no divinity save The Divinity!" Thus, peace-making initiatives were abrogated by a universal call upon the Muslims to pursue jihād as imperial conquest. Al-Ṭabarī explicitly asserts that such an interpretation "has no evidence in Revelation, nor in Prophetic practice, nor in the innate human constitution of reason/fitrata 'aql!" 11 He strongly denies the widespread allegation that the divine bidding to respond to peaceful initiatives of peace-making with a corresponding peaceful conciliation was ever actually abrogated.

\section{Abode of Security?}

Only one classical legal concept will be glanced at here, notwithstanding the doubtful relevance of such divisions for today's world. Muslim jurists constructed the territorial concept of the dār al-islām: all territory under the direct authority 
of Muslims, whether built and settled by them, or whose inhabitants had yielded willingly to Muslim authority, or had been conquered by force of arms, or with a peaceful treaty. Non-Muslims in these territories were to pay the jizyah (poll-tax) as a sign of submission to Islamic authority. Outside of this territory lay areas controlled by non-Muslim powers, termed the 'Abode of War' (dār al-harb) as the proper sphere for conducting jihād. This juristic division of the world viewed the domain ruled by Islamic polity as comprising the 'Abode of Security' ( $d \bar{a} r$ al-islām), wherein both Muslims and non-Muslims mutually cooperate beneath the umbrella of the larger Islamic society. In this conceptual polarity of islām $\leftrightarrow$ harb, al-isläm is best understood here to specifically refer to the security enforced by the governing polity and social order upheld by the Faith. This outmoded juridical doctrine underlines the integral association of Islam's conception of 'peace' with 'security' - a connection lost in the common English translation 'Abode of Peace'.

\section{Conclusion and Recommendation}

The relevance of religious ideals to 'human security' appears to find a particularly compelling example in Islam. This invites more intensive exploration and should be integrated with current discussion about deepening the understanding of security to include spiritual and ethical components. Complementing its emphasis on just polity and an equitable social order, Islam offered specific ideals and practices for active reconciliation between individuals and groups. Islamic teachings thereby sought a balance between the political dictates of justice and equity, and those of human clemency, harmony, and selfless love embraced by the ideal of al-ihssān, 'surpassing goodness':

Surely God enjoins justice and 'doing-good-to-others' (al- 'adl wa 'l-iḥsān), and giving [to others] like unto [one's own] kin, and forbids indecency and manifest evil and unjust oppression. (Qur'ān 16:90)

\section{Notes}

1. UNDP, Human Development Report 1994: New Dimensions of Human Security (New York: Oxford University Press, 1994).

2. Commission on Human Security, Human Security Now: Final Report (New York: CHS, 2003).

3. See in particular David Baldwin, "The Concept of Security, Review of International Studies 23, no. 1 (1997), 5-26, and John Baylis, "International Security and Global Security in the Post-Cold War Era", in: John Baylis and Steve Smith (eds), The Globalisation of World Politics: An Introduction to International Relations (Oxford: Oxford University Press, 2005, 3rd ed.), 297-324. Many security establishments now accept the widened concept of 'non-traditional security', embracing natural disasters and ecological degradation.

4. Shahrbanou Tadjbakhsh, "Human Security: Concepts, Application and Implication", Etudes du CERI, no.117-18 (Paris: CERI, September 2005). See also: "What is 'Human Security'? Comments by 21 Authors", Security Dialogue 35, no. 3 (2004), 347-87. 
5. But note the current Arabic term for pacifism, hubb al-silm. Juridical usage also equated al-sulh with al-silm, 'ending the state of war'.

6. See Qur'ān 8:1, 4:35, 4:114, 49:9-10, and passim.

7. The great Kufan jurist Abū Hanīfah (d. 767) included this utterance among his choice of five of the weightiest Prophetic hadìths crucial for faith.

8. With confirmatory reference to Qur'ān 49:9. See Ibn Jarīr al-Tabarī, Jāmi ' al-bayān fì ta 'wīl al-Qur'ān, ed. Hānī al-H̄ājj et al. (Cairo: al-Maktabat al-Tawfĩqiyyah, n.d.), 2:363-66, and al-Māturīdī, Ta'wīlāt al-Qur'ān (Istanbul: n.p., 2005), 1:412.

9. al-Ṭabarī, Jāmi 'al-bayān, 10:35-7.

10. Ibid., 2:364.

11. Ibid., 10:36. Al-Ṭabarî̀'s juridical law rite, the Jarīrī madhhab, was noted for its rational orientation and therefore condemned by Traditionalist Hanbalīs. 